\title{
Moved to Tears: Erwin Koch and Emotional ENGAGEMENT IN LITERARY JOURNALISM
}

\author{
Kate McQuEEN ${ }^{1}$
}

\begin{abstract}
Journalism research broadly has begun to acknowledge a fact long accepted in the field of literary journalism: that emotional engagement can be an advantageous trait of a reported story. But there is still much to learn about how journalistic texts facilitate emotional involvement in readers. This article adds to this body of knowledge in two ways. It explores the history and theory of emotional appeals in literary journalism, and it offers an analysis of the stylistic strategies of emotive Swiss literary journalist Erwin Koch. Koch succeeds in eliciting both strong emotion and critical acclaim by using a condensed yet distanced narrative style, which is particularly effective at mirroring his subjects' experience of being in the world. Through analysis of Koch's work and its reception, this article offers insight into the nature of immersive reading experiences and points to opportunities for future research on the topic of affect in literary journalism.
\end{abstract}

When Swiss journalist Erwin Koch published his collections of reportage-Was das Leben mit der Liebe macht. Wahre Geschichten (What Life does to Love. True Stories) in 2011 and Von dieser Liebe darf keiner wissen. Wahre Geschichten (Of this Love No One May Know. True Stories) in 2013 - professional critics and lay readers praised the books with strikingly similar language.

1 Kate McQueEn is a Lecturer at University of California Santa Cruz.

Recherches en communication, $\mathrm{n}^{\circ} 51$ - Article publié le 10/09/2020 
"Erwin Koch's stories get under the skin," Neue Luzerner Zeitung reviewer Stefan Christen wrote. For Deutschlandfunk Kultur radio, literary critic Jörg Magenau agreed, "None of these stories leave a reader cold." 2 Amazon customer reviewers found the stories likewise "rousing" (Jennifer Paasch) and "stirring" (Gerber André). "They took hold of me," Gabriela Widmer reported. "Erwin Koch's reportage," so Reinhard Lahme, "leaves no one untouched."

In addition to this lively collection of embodied metaphors, Koch's readers also report a physical involvement of the more literal kind. Take, for instance, the online comments accompanying "260 Tage" (“260 Days"), a piece from Koch's 2013 collection published digitally a year earlier in Die Zeit:

"My tears fell constantly while reading." (El_Presidente)

"I consider myself to a certain extent hardened to such things, but here I had to two take two breaks while reading, in order to cry." (Rabe72)

"Tear-jerker. Read the article in the paper and was similarly choked up like my fellow commentators." (ickbinick)

Tears - like laughter, goose bumps, or cold sweat — are often a physiological indication of deeply felt emotion, a term defined here as the interpretation of bodily sensations in response to stimuli, which can be shared and acted upon (Massumi, 2002; Leys, 2017; Wahl-Jorgensen, 2019). Their presence in the reading experience at large is not particularly controversial. Since Aristotle's Poetics, emotions have been acknowledged as a meaningful aspect of our interaction with works of literature. Koch's readers might even expect heightened proprioception, considering the intentionally emotional quality of his subject matter. In a 2017 interview with the Luzerner Zeitung, the author reflected that his reported work foregrounds "existential themes" such as "[l]ove, desire, treachery, illness, suffering, death" over the more standard choice of "sociopolitical occurrences" (Bossart). His oeuvre includes stories about illness-ravaged children, dying spouses, illicit

2 All translations from the German are mine. The quotes by Christen and Magenau are included in the press commentary on the Amazon.de product page for Koch's book Von dieser Liebe darf keiner wissen. Wahre Geschichten. Retrieved from https://www.amazon.de/dieser-Liebe-darf-keinerwissen/dp/3312005574/ref=cm cr_arp_d_product_top?ie=UTF8 
romance, blood feuds, and execution-material explored by literary tragedy, and well within the journalistically treacherous territory of the sensational.

More surprising may be Koch's ability to elicit tears and critical acclaim, given the fraught nature of aesthetic emotion in the journalistic context. It is still commonplace for emotions to be taken as "a marker of unprincipled and flawed journalism" (Peters, 2011, p. 297). Yet Koch is readily identifiable as one of the most important literary journalists working in the German language today (Eberwein, 2013). His articles have been a staple of prestigious weeklies like Der Spiegel, Die Zeit, and Süddeutsche Zeitung Magazin since the 1990s, and have twice earned him the Egon-Erwin-Kisch Prize, an annual award for the best German-language journalism.

This article takes up this productive tension between Koch's unusually emotive material and his strong critical reception in order to explore how literary journalists evoke emotional response in readers. The key to Koch's success, as argued below, is his unusual style, a condensed narrative approach he calls Verknappung. The primary focus will be a close reading of an exemplary Koch text called "Das Ende der Scham" ("The End of Shame"), and its reception. Drawing on scholarship from the field of cognitive narratology, this analysis suggests that his narrative condensation evokes strong emotive response because it is particularly effective at mirroring his subjects' experience of being in the world. Moreover, it does so without foregrounding authorial subjectivity through first-person narrative, a strategy commonly used in literary journalism to expand the emotional dimensions of a text (Harbers \& Broersma, 2014; Tulloch, 2014).

Koch fits into a long line of journalists of who have made strategic use of emotion, so this essay begins with background on the history and theory of emotional appeals in literary journalism before turning to textual analysis. And since emotional experience is often understood to consist of three elements - elicitation, expressive outcome, and actional response (Hogan, 2011) — the essay concludes with some thoughts about the stakes of provoking emotional engagement through literary journalism. Koch's articles are a useful place to explore elicitation (the poetics of affect) and to gain insight into the nature of immersive reading experience. The question of impact, though, is more difficult to answer through the lens of Koch's work. With this in mind, this essay will also point to opportunities for future research on the topic of affect in literary journalism. 


\section{Emotion, Narrative, and Literary Journalism}

Modern mainstream journalism has always held ambivalence for the teary-eyed reader, and for the reporter who elicits such a reaction. Karin Wahl-Jorgensen traces this "profound institutionalized resistance to the idea of emotion" to the field's professionalization in the early twentieth century $(2019 ; 2013$, p. 131). Coming of age in an era that valorized positivism and belief in rationality, the press took up the mandate to "report only the facts" using a "cool, rather than emotional" tone (Schudson, 2001, p. 150). Journalistic objectivity became positioned in opposition to emotional expression of all kinds, most of all to the "sensationalist excesses" of the press' tabloid wing, which advocated, entertained, and generally drove sales by appealing to feelings independent of, or even in opposition to, reason (Wahl-Jorgensen, 2019, p. 31). Conflation of emotionality with tabloid practices, as Chris Peters (2011) points out, has been a perennial problem for journalism practitioners and for scholars, who have tended to link use of emotions with a decline in journalistic standards and a breach of journalism's informational role.

The continuous publication of literary journalism from the late nineteenth century onwards, however, suggests that strategic use of emotion was not uniformly contested. From its earliest iterations, this journalistic form distinguished itself from mainstream practice not only by employing "narrative and rhetorical techniques generally associated with fiction" but by presenting the "feel" of the facts" (Connery, 1991, p. XVI; Connery, 1990, p. 6). In this respect, early literary journalism shares notable overlap with both journalistic sensationalism (Hartsock, 2000) as well as the sentimentalism of contemporaneous popular literature (Fitzgerald, 2017).

Overlap occurs in mutual concerns over poverty, crime, corruption, and other forms of injustice, which animated similar choice of content. This is true in the English-language and German-language contexts (Hartsock, 2000; Geisler, 1982; Michael, 2019). Selection of discourse mode is another matter. Sensationalist reports, Hartsock explains, leaned heavily on discursive modalities, and the literary report remained centered in narrative. These choices support what Hartsock calls the "epistemological intention" of the text. The sensationalist report employed rhetorical choices that tended to "insight outrage" or shock (p. 139) but "reduce the experience of the other into a framed spectacle" (Berger, quoted in Hartsock, p. 141), while the literary report 
managed to "narrow the distance between the subjectivity of the journalist and the reader on the one hand and the objectified world on the other" (p. 141) and generate "empathic response" (p. 145). In other words, a crucial cohort of journalists have always understood that feelings need not work at cross-purposes with knowledge; they could in fact be a vital source of understanding when they are generated through the reader's imaginative processing of the experiences represented in texts.

Research on the link between journalistic form and emotion in more recent works of reporting - both standard and self-consciously literary-has come to similar conclusions. Peters (2011), WahlJorgensen (2013, 2019), and Maier, Slovic, and Mayorga (2017) indicate that the strongest instances of emotional response tend to come from journalism using narrative techniques, specifically ones that create a sense of identification with the subjects presented in a text. These include: personalized narration in the form of anecdotal leads, journalist-centered first-person point of view, and interior representation of subjects' emotional states provided through descriptive or emotive language, as well as expressions of affect in word choice. Like Hartsock, these scholars make the case that narrative-mediated identification fosters understanding, aids in processing news information (Maier et al., p. 1014), and even "enables rational consideration of the issue at hand" (Wahl-Jorgensen, 2013, p. 132).

Such consensus gives substantial credence to the idea that emotions play a salutary part in journalism's informational role, when delivered in narrative form. But there is still much to be learned about how narrative manages this accomplishment. In order to more deeply explore the mechanics of the dynamic between narrative journalism and emotion, this essay turns to theoretical work in cognitive narratology. Scholars in this post-structuralist field have been combining traditional interpretive analysis of literary texts with empirical research in order to better understand the affective dimensions of the reading experience. This includes, for instance, using cognitive reception theory to explain narrative empathy (Keen, 2006, 2007), or synthesizing cognitive science and phenomenology to explore embodiment and situatedness (Caracciolo, 2011, 2013, 2014, 2018).

Central to these lines of inquiry is the concept of experientiality, a term introduced by Monika Fludernik in her book Towards a 'Natural' Narratology (1996), to describe the "mimetically motivated evocation of human consciousness and its (sometimes chaotic) experience 
of being in the world" found in all narrative (p. 30). Fludernik uses the term to redefine narrativity away from the narrow "teleology of plot" and towards a grander concept of embodiment, which "evokes all the parameters of a real-life schema of existence," including "emotional involvement with experience and its evaluation" (p. 30). This, Fludernik argues, "provides the cognitive anchor point for the constitution of narrativity" (p. 13).

There are a few reasons why the collective work around Fludernik's narrative theory is useful for analysis of literary journalism. For one, it foregrounds conversational narrative over formal forms of fiction, theorizing narrative patterns that transpose with ease onto works of journalism, a reported form of literature itself based in "naturally occurring" storytelling. Additionally, redirecting critical attention away from plot-focused discussion of narrative encourages analytical focus to fall instead on elements like story environment, character, and narrative perspective. These elements place in central view strategies that communicate the thoughts, feelings, perceptions, and sensations of the story in order to provide the audience with an immersive reading experience, an important but relatively under-theorized element in the study of literary journalism.

\section{Koch's Representation of Experience though Condensation}

With experientiality in mind, this essay returns to Koch, who once described his journalistic goals in reverse terms: to avoid producing the "kind of dumbed-down journalism that deprives the reader of sharing in all potential thinking, experiencing, and suffering" (Koch \& Cox, 2011, p. 40). The flood of tears cited at the beginning of this article makes clear he's had some success with this objective. Tears may indicate distress, or relief from it, as we know from Aristotle's discussion of catharsis. They may also signal empathy, that "vicarious, spontaneous sharing of affect... provoked by witnessing another's emotional state" (Keen, 2006, p. 208). In Koch's writing, such sharing starts at the level of content. He focuses on universally relatable narratives - often love stories, as the titles of his collections indicate - that contain with what he calls a "false bottom" (p. 41). It's a choice that increases the likelihood of familiarity with the experience represented in the text, a key factor in its cognitive evaluation, while retaining space for controversial or easily overlooked issues. 
This dynamic stands out with some force in Koch's article "Das Ende der Scham", originally published in the Swiss Magazin SonntagsBlick in 2007, and later included in the collection Von dieser Liebe darf keiner wissen. The love driving this story is filial. But the stakes are explicitly political. Koch tells the story of Briton Gertrude Harris, the 94-year-old daughter of a man executed for cowardice during the First World War. After 14 years of advocacy, Harris succeeds in securing a pardon for her father and the 305 British soldiers who shared his fate. This rehabilitation, publicly commemorated in London by representatives of church and state, brought an abandoned group of soldiers back into the national fold. It also allowed their families to finally participate freely in the national story of war loss and memory.

There are many tears in this story. In fact, embodied display of emotion holds a crucial, thematically central role in its telling. There are Harris's tears, suppressed and hidden for 80 years before they finally fall in public. There are her father Harry Farr's tears too, as well as his shaking, and his loss of speech and other bodily functions, after the battles of Neuve Chapelle, Aubers Ridge, and the Somme. Unlike Harris, Farr's body is unable to suppress and hide feeling; he is labeled a coward and shot at dawn. And in the end, there is Harris's own shaking hand, laying down a wreath of red flowers with a gentle request for rest in peace.

What keeps this sentimental content from tipping into melodrama is a unique style Koch calls Verknappung (Freitag). The German word translates directly as "shortening." But Koch's technique is better suited by the looser translation "condensation," since it is particularly effective at offering concentrated experiential richness for the reader, what Marco Caracciolo, in the spirit of Clifford Geertz, calls "'thick' embodied simulation" (2018). Specifically, Koch's condensation intensifies representation of consciousness, space, and temporality, making the felt life of his subjects all the more vivid. Consider the article's first sentence, which demonstrates many forms of condensation readers find on steady repeat throughout the text:

Now Gertrude Harris cries, who hardly cried when her men died, father, stepfather, half-brother, son, husband, but I shouldn't be ashamed that I am crying now, Gertie is ninety-four, a great-grandmother, her bottom lip quivers, Gertie didn't cry when she fell off the sidewalk months ago and broke her hip, she sits in a wheelchair and cries 
under the sky of Harrow Wealdstone, London, her feet, in grey slippers, are packed in thick grey socks, seagu1ls scream, it is Sunday afternoon in February, and on the street the police pull over cars. (Koch, 2011, p. 51)

Koch primes readers for feeling by opening with Harris at a moment of emotional expression. The fact of her tears is repeated not once but three times, accompanied by a dense sequence of scenic details, which provide the look, sound, and feel of the setting with unmistakable affective overtone. Much included here is emotionally over-determined and tinged with sadness - screaming seagulls, the wheelchair, the color grey. The same is true for the biographical details included at the beginning of the sentence, which reveal a brief but telling personal history of pain and loss, endured with stereotypically British fortitude.

To the condensation of detail and time, Koch often compresses of points of view. In this opening sentence he does so by interrupting his otherwise distanced third person narration with a clause from Harris's perspective ("I shouldn't be ashamed that I am crying now"). Rendered without quotation marks but in the first-person voice, the shift between consciousness attribution and enactment- to use Caracciolo's termshas a few consequences $(2014$, p. 110). First, the reader gains access to an internal evaluation of Harris's affective state, which helps readers gauge how complicated the emotions related to her tears are. The first remark, "I shouldn't be ashamed," indicates she is both experiencing shame and judging it inappropriate, followed a few paragraphs later by the question to herself about the permissiveness of her response: "but now I'm allowed to cry, aren't I?" Second, like stream of consciousness, which it closely resembles, the condensation of voice promotes a greater sense of immediacy. As the article progresses in similarly condensed fashion through the intertwined life stories of Harris and Farr, the nesting points of view allow present-day scenes to be interrupted with a flood of personal memory and historical facts.

Unorthodox punctuation, syntax, and sentence length reinforce the compression. In "Das Ende der Sham," Koch employs very few full stops and no quotation marks. The opening sentence is a case in point, containing 92 words, 17 commas, and one period. The effect of this structure is breathlessness, which, not unlike suspense, can increase involvement in the narrative outcome, even independent of character identification (Wünsch, 1981). It's worth noting that Koch does not always favor long sentences. Other articles by Koch make use of the 
opposite extreme, short sentences assembled in an almost list-like manner on the page. Regardless of length, his sparse use of punctuation remains consistent, lending the work an idiosyncratic appearance compatible with what David S. Miall (1989) calls foregrounding, a process of defamiliarization that slows reading pace and invites a more engaged reading experience.

Used together, these various techniques of narrative condensation mimic the experience of Harris' emotional state over the course of the story and urge the reader to share in her experience. This process is aided by one further element: the author's absence. Koch's work maintains the controlled, depersonalized third-person narration readers are likely to expect from standard reporting, instead of the foregrounded authorial subjectivity popular in much literary journalism (Harbers \& Broersma, 2014; Tulloch, 2014). For as much as Koch keeps the reader tracked closely to the suffering of his subjects, he offers no editorializing and only little exposition or descriptive language. Instead, the emotional work is managed by the products of Koch's reporting, carefully arranged on the page.

This is, one might expect, the quality that Neue Züricher Zeitung's Alexandra Stäheli has in mind when she praises Koch's "protocolic plainness" - the ability of his work to resemble at times a bureaucratic document, in tone and occasionally in structure. In her review of Koch's second collection, Stäheli likewise wonders if "sometimes his [plain] narrative approach-out of respect for the manipulative effect of a feeling all-together too big-lets the social drama come even more dramatically into being in the space of the story." It's easy to imagine how one more voice and one more set of experiences playing out on the page - particularly one as prominent as the author's - might amplify the feeling in this strongly affective material to an unbearable register, and push the reader from a position of openness to avoidance. Suzanne Keen (2006) describes this response as empathic aversion, which causes distressed readers to close their books. In this respect, Koch's narrating distance seems a necessary ingredient to enable full emotional response in his readers, in sync with the longstanding idea, from Kant onwards, that both distance and immediacy are needed to foster a full aesthetic experience. 


\section{What to Do With All the Feeling? Reflections on Future Directions of Study}

Patrick Colm Hogan (2011) has pointed out that emotional experience consists of three elements - elicitation, expressive outcome, and actional response. Much expectation rests on this last element. Writers and critics alike are deeply invested in the notion that emotions produced through storytelling don't simply entertain but inform, persuade, or even spur audiences into action, in the best scenarios with desirable social outcomes. According to Peters (2011), Maier et al. (2017), and Wahl-Jorgensen (2019), this is particularly true in reference to journalistic storytelling.

We find traces of this expectation in "Das Ende der Scham," both in the text's ideology and in its reception. The article is centered in the felt life of Gertrude Harris, and in a significant way this is a story about her personal pain. At the same time, the dominant emotionnamed in the title and described in the text-is shame, a feeling that only manifests through recognition of social expectations. In this sense, Koch's choice of emphasis gives Harris's private experience a substantial public dimension. This choice also optimally positions the reader to transfer empathy felt for Harris personally to her cause, a consequential political and social reorientation that looks back at soldiers condemned as traitors and sees men who were "not cowards but sick from war" (p. 60).

The article's reception and publication history help us gauge, to some extent, the effectiveness of Koch's narrative in delivering emotional transfer. The Shot at Dawn movement received a small amount of news coverage in England around the time of Farr's pardon, in the summer of 2006, and little to no attention outside the country's borders. But "Das Ende der Scham" was published by two national media outlets in the German-speaking world, the Swiss Magazin SonntagsBlick and the Austrian newspaper Die Presse, and prompted a reader comment on the latter's website about the relevance of the story for Austria: "An impressive and distressing story. Is there an investigation over similar cases for Austria-Hungary [in] the First World War?" This history holds significance because it indicates that Koch's storytelling has the ability to attract readers to stories beyond the borders of geographic relevance and traditional newsworthiness. It also highlights socially important outcomes that have less to do with audience response, like diagnosis and witness bearing. 
The small scale of reception, however, excludes broader assessment of impact. As the digital presence of narrative journalism continues to grow, it will be worth considering whether viral magazine stories, or those collected in book form and reviewed online, generate more statistically meaningful responses about the outcome of reader engagement. Until then, the most likely source of insight into action-based outcomes from literary journalism are larger-scale empirical studies, like Maier et al.'s (2017) survey-driven experiment that linked narrative newsdriven emotional response to the likelihood of charitable giving.

The stylistic parameters of Koch's work also point to opportunities for future analysis in the area of elicitation. As this essay has shown, Koch demonstrates how it is possible to create an emotionally intense, immersive reading experience using a distanced third-person narrative perspective. His exclusionary use of this approach, however, leaves unanswered questions regarding the nature and use of emotional experience in first-person narration. Does the representation of the journalist's experience in the form of the "dramatized narrator" (Booth 1983), for example, make room for an emotional register as wide as the cathartic feelings in Koch's texts? This question is particularly interesting in light of the fact that literary-journalistic first-person narratives often make use of irony and non-cathartic, so-called "ugly feelings" (Ngai, 2005), like anxiety, irritation, exasperation, and disgust. Taking this into consideration, Koch can serve as essential reference point as literary journalistic scholarship further explores the narrative performance of affect.

\section{References}

André, Gerber. (2013, May 20). Wunderbare Geschichten [Review of Von dieser Liebe darf keiner wissen: Wahre Geschichten]. Amazon.de. Customer Reviews. Retrieved from https://www.amazon.de/dieser-Liebe-darf-keiner-wissen/product-reviews/3312005574/ref=cm_cr_dp_d_show_all_btm?ie=UTF8\&reviewerType=all_reviews/.

Auch für Österreich relevant? (2007, September 8) Die Presse. Retrieved from https:// diepresse.com/home/spectrum/zeichenderzeit/328712/Das-Ende-der-Scham\#

Booth, Wayne C. (1983). Rhetoric of fiction. Chicago, IL: University of Chicago Press.

Bossart, Pirmin (2017, October 1). Autor Erwin Koch: 'Ich komme, wenn es schon passiert ist”. Luzerner Zeitung. Retrieved from https://www.luzernerzeitung.ch/kultur/ schreiben-autor-erwin-koch-ich-komme-wenn-es-schon-passiert-ist-ld.123841

Caracciolo, Marco (2011). The reader's virtual body: Narrative space and its Reconstruction. Storyworlds 3, 117-138. 
Caracciolo, Marco (2013). Blind reading: Toward an enactivist theory of the reader's imagination. In Lars Bernaerts, Dirk de Geest, Luc Herman \& Bart Vervaeck (Eds), Stories and minds: Cognitive approaches to literary narrative (pp. 81-106). Lincoln, NB: University of Nebraska Press.

Caracciolo, Marco (2013). Experientiality. In Peter Hühn, Christoph Meister, John Pier, Wolf Schmid (Eds.), The Living handbook of narratology. Hamburg, Germany: Hamburg University. Retrieved from http://www.lhn.uni-hamburg.de/article/ experientiality.

Caracciolo, Marco (2014). The experientiality of narrative: An enactivist Approach. Berlin, Germany: De Gryter.

Caracciolo, Marco (2018). A walk through deep history: narrative, embodied strategies, and human evolution. Ghent, Belgium: University of Ghent. Retrieved from https:// biblio.ugent.be/ publication/8560105/file/8560106.pdf

Cl.borries. (2011, September 7). Lebensbilder [Review of Was das Leben mit der Liebe macht: Wahre Geschichten]. Amazon.de. Customer Reviews. Retrieved from https://www.amazon.de/Was-das-Leben-Liebemacht/productreviews/3548611214/ ref $=$ cm_cr_dp_d_show_all_btm?ie $=U T F 8 \&$ reviewerType $=$ all_reviews/

Connery, Thomas B. (1991). A sourcebook of American literary journalism: Representative writers in an emerging genre. New York, NY: Greenwood Press.

Connery, Thomas B. (1990). A third way to tell the story: American literary journalism at the turn of the century. In Norman Sims (Ed.), Literary journalism in the twentieth century (pp. 3-20). New York, NY: Oxford University Press.

Eberwein, Tobias (2013). Literarischer Journalismus: Theorie, Traditionen, Gegenwart. Cologne, Germany: Herbert von Halem Verlag.

El_Presidente. (2012, December 27). Tränen [Comment on article 260 Tage]. Zeit Online. Retreived from https://www.zeit.de/2013/01/Kind-Krankheit-Abschied\#comments.

Fitzgerald, Jonathan D. (2017). Nineteenth-century women writers and the sentimental roots of literary journalism. Literary Journalism Studies 9(2), 8-27.

Fludernik, Monika (1996). Towards a 'natural' narratology. London, UK: Routledge.

Freitag (2014, December 29). Freitag am Donnerstag/Erwin Koch (Zürich) [Video file]. Retrieved from https:/www.youtube.com/watch?v=mbzuNoVvdZI.

Geisler, Michael (1982). Die literarische Reportage in Deutschland: Möglichkeiten und Grenzen eines operativen Genres. Königstein, Germany: Scriptor.

Harbers, Frank \& Broersma, Marcel (2014). "Between engagement and ironic ambiguity: mediating subjectivity in narrative journalism," Journalism 15(5), 639-654.

Hartsock, John (2000). A history of American literary journalism: The emergence of a modern narrative form. Amherst, MA: University of Massachusetts Press.

Hartsock, John (2016). Literary journalism and the aesthetics of experience. Amherst, MA: University of Massachusetts Press.

Hogan, Patrick Colm. (2011). Affective narratology: The emotional structure of stories. Lincoln, NB: University of Nebraska Press.

Ickbinick (2012, December 30). Zum heulen [Comment on article 260 Tage]. Zeit Online. Retreived from https://www.zeit.de/2013/01/Kind-Krankheit-Abschied\#comments.

Keen, Suzanne (2006). A theory of narrative empathy. Narrative 14(3), 207-236.

Keen, Suzanne (2007). Empathy and the Novel. Oxford, UK: Oxford University Press. 
Koch, Erwin \& Cox,John K. (2011).Tales of happiness and misery: A conversation with Erwin Koch. World Literature Today 85(2), 38-42.

Koch, Erwin. "Das Ende der Scham," Die Presse, 7 September 2007. http://diepresse. com/home/spectrum/zeichenderzeit/328712/Das-Ende-der-Scham

Koch, Erwin. "Freitag am Donnerstag/Erwin Koch (Zurich)" https://www.youtube. com/watch? $=$ mbzuNoVvdZI

Koch, Erwin (2013). Von dieser Liebe darf keiner wissen. Wahre Geschichten. Munich, Germany: Verlag Nagel \& Kimche.

Koch, Erwin (2011). Was das Leben mit der Liebe macht. Wahre Geschichten. Munich, Germany: Corso Verlag.

Lahme, Reinhard (2013, December 23). Die Liebe und das Leben [Review of Was das Leben mit der Liebe macht: Wahre Geschichten]. Amazon.de. Customer Reviews. Retrieved from https://www.amazon.de/Was-das-Leben-Liebe-macht/productreviews/3548611214/ref=cm_cr_dp_d_show_all_btm?ie=UTF8\&reviewerType $=$ all_ reviews/

Leys, Ruth (2011). The turn to affect. Critical Inquiry 37(3), 434-472.

Magenau, Jörg (2012, January 9). Kleine Liebesgeschichten ganz groß [Review of Was das Leben mit der Liebe macht. Wahre Geschichten]. Deutschlandfunk Kultur. Retrieved from https://www.deutschlandfunkkultur.de/

Massumi, Brian (2002). Parables for the virtual. Durham, NC: Duke University Press.

Maier, Scott R., Slovic, Paul, \& Mayorga Marcus (2017). Reader reaction to news of mass suffering: Assessing the influence of story form and emotional response. Journalism 18(8), 1011-1029.

Miall, David S. (1989). Beyond the schema given: Affective comprehension of literary narratives. Cognition and Emotion 3, 55-78.

Michael, Hendrik (2019). Die Darstellung der Unterschicht im wilhelminischen Berlin durch Sozialreportagen der Massenpresse. Medien \& Zeit 34(2), 3-13.

Ngai, Sianne (2005). Ugly feelings. Cambridge, MA: Harvard University Press.

Paasch, Jennifer (2014, June 28). Feedback [Review of Was das Leben mit der Liebe macht: Wahre Geschichten]. Amazon.de. Customer Reviews. Retrieved from https:// www.amazon.de/Was-das-Leben-Liebe-macht/product-reviews/3548611214/ ref $=$ cm_cr_dp_d_show_all_btm?ie $=U T F 8 \&$ reviewerType $=$ all_reviews/

Peters, Chris (2011). Emotion aside or emotional side? Crafting an 'experience of involvement ' in the news. Journalism 12(3), 297-316.

Rabe72. (2012, December 29). Sprachlos [Comment on article 260 Tage]. Zeit Online. Retreived from https://www.zeit.de/2013/01/Kind-Krankheit-Abschied\#comments.

Schudson, M. (2001). The objectivity norm in American journalism. Journalism 2(2), 149-170.

Stäheli, Alexandra (2011, September 29). Attacke des Lebens auf die Liebe [Review of Was das Leben mit der Liebe macht. Wahre Geschichten.] Neue Zürcher Zeitung. Retrieved from https://www.nzz.ch/attacke_des_lebens_auf_die_liebe-1.12714843

Tulloch, John (2014). Ethics, trust and the first person in the narration of long-form journalism. Journalism 15(5), 629-638.

Wahl-Jorgensen, Karin (2013). The strategic ritual of emotionality: A case study of Pulitzer prize-winning articles. Journalism 14 (1), 129-145.

Wahl-Jorgensen, Karin (2019). Emotion, media, and politics. Medford, MA: Polity Press. 
Widmer, Gabriela (2015, July 12). Dieses Buch berührt! [Review of Was das Leben mit der Liebe macht: Wahre Geschichten]. Amazon.de. Customer Reviews. Retrieved from https://www.amazon.de/Was-das-Leben-Liebe-macht/productreviews/3548611214/ref=cm_cr_dp_d_show_all_btm?ie=UTF8\&reviewerType=allreviews/

Wünsch, Marianne (1981). "Verhältnis von Interpretationen und Rezeption: Experimentelle Untersuchungen am Beispiel des Theodor Storm-Textes.“ In H. Kreuzer and R. Viehoff (Eds.), Literaturwissenschaft und empirische Methoden: eine Einführung in aktuelle Projekte (pp. 197-225). Göttingen: Vandhoeck und Ruprecht.

\section{(c) $(1) \Theta(\Theta$}

«Attibution - pas d'utilisation Commerciale - Pas de Modification 4.0. International» (CC BY-NC-ND) 